\title{
ORCHESTRATING ANTI-DISPOSSESSION POLITICS: CASTE AND MOVEMENT LEADERSHIP IN RURAL WEST BENGAL
}

\author{
Kenneth Bo Nielsen (k.b.nielsen@ikos.uio.no) \\ Department of Culture Studies and Oriental Languages
}

University of Oslo

\begin{abstract}
This article uses the concepts of orchestration and spectacle to analyse the work of leaders of an anti-dispossession movement in rural West Bengal. The article examines what being a movement leader entails, and argues for the importance of connections and social relations in the production of both movement leadership and movement spectacles. By introducing a Dalit perspective on a movement that was otherwise lead by the local middle-caste peasantry, the article shows how local caste-class relations have been important in defining access to positions of movement leadership; in disconnecting specific Dalit interests from the movement's larger political agenda; and in giving rise to certain forms of internal policing of caste boundaries within the movement. The fact that the ability to cultivate and 'connect' to the new political spaces opened up by the anti-dispossession movement correlated strongly with historically produced caste-class inequalities calls for greater attention to the internal caste-class politics of anti-dispossession movements.
\end{abstract}


During fieldwork in Singur in rural West Bengal, India, in late 2007 I occasionally had the chance to sit down and talk with Dipak Koley, one of the most important local leaders of an anti-dispossession movement that had emerged in 2006 to stop the Indian car manufacturer Tata Motors from taking control of around 1,000 acres of fertile farmland. I say occasionally because, as a movement leader, Dipak was almost constantly on the move. On his motorbike he visited dispossessed villages across the area, went to meetings with supportive civil society activists and NGOs, spoke at meetings and rallies, liaised with political leaders from different parties, or strategized with his fellow movement leaders. During this particular conversation we spoke about our recent visit to the nearby village of Nadipara, where the inhabitants had almost uniformly rallied behind the anti-dispossession movement that Dipak Koley led. Unlike Dipak - who belonged to the locally dominant intermediate Mahishya caste who were traditionally owner-cultivator agriculturalists - the overwhelmingly landless inhabitants of Nadipara were all Dalits, that is, they belonged to the formerly untouchable castes.

Now, Dipak shared his concerns about the depth of the Dalits' commitment to the movement: 'These people are poor. They are not educated,' he said. If people who supported the Tata Motors project came to Nadipara and 'gave them something and told them something', as he put it, the Dalits could easily be persuaded by empty promises of immediate material benefits and lured away from the movement by its detractors, he feared. The movement's Dalit supporters were also an unruly lot, he added. They lacked 'the method' that any sustained movement must have, and were prone to carry out their resistance through sporadic attacks or random stone pelting at the heavily guarded concrete wall that now separated the surrounding villages from the land that had been acquired for Tata Motors. In this regard, the Dalits had proven themselves useful as movement foot soldiers. But, such actions would in effect change nothing on the ground, Dipak lamented - it would only give the guards and the police an excuse to attack and beat up anti-dispossession activist. These spontaneous actions were thus 
a waste of one's energy and only risked causing unnecessary bloodshed. What was required to successfully carry the movement forward was rather 'method' and 'instructions', and as a movement leader Dipak was evidently ready to provide both (based on the author's field notes).

While anti-dispossession movements have been a near-ubiquitous feature of India's new land wars (Levien 2018) there is still a limited literature on the modalities and practices of leadership that go into the making of such movements at the local level. To address this gap, this article offering an ethnographic analysis of the grassroots work of anti-dispossession activists and leaders in a land conflict in Singur in rural West Bengal, one of India's earliest and most talked-about new land wars. To foreground the question of movement leadership, the article addresses the following questions: How and why do certain people emerge as movement leaders? What do they do when they lead, and how are their actions and repertoires geared towards energising anti-dispossession politics? While these questions are significant in their own right, they also serve as an important point of entry for analysing how caste is - as alluded to in the opening vignette - crucially implicated in anti-dispossession politics. As will be shown later, in Singur locally dominant owner-cultivators from intermediate caste backgrounds occupied positions as movement leaders, whereas the overwhelmingly landless Dalit labourers were largely absent from the leadership and relegated to the role of 'foot soldiers'. The fact that the movement's organisational set-up thus came to correlate strongly with local inter-caste relations, however, did not go uncontested. This article thus aims to 
bring out how caste both shapes anti-dispossession politics and movement leadership, while also being politicised through collective mobilisation.

The twin issues of movement leadership and caste are pursued by zooming in on two aspects of the work of Dipak Koley. The article first illustrates how he, as a member of the locally dominant Mahishya caste, emerged as a local leader who could take charge of orchestrating the movement. While much of this orchestration was directed at public spectacles and events that sought to erase caste from the movement's vocabulary, it also had a more hidden side that involved the construction of an internal core-periphery structure along caste lines, a structure that pushed specific Dalit agendas to the margins of the movement's discursive field.

Below the discussion is situated in the broader context of India's new land wars; we then historicise the relationship between caste, power and leadership in rural India, with particular reference to West Bengal; lastly, we engage the above questions more directly through two extended ethnographic cases drawn from my fieldwork in Singur carried out periodically between 2007 and 2009. ${ }^{1}$ The ethnography that is presented is based on participant observation in and of movement activities and meetings, as well as unstructured and semistructured interviews and household surveys in two villages.

\section{India's New Land Wars}

The liberalisation of the Indian economy over the past three decades has increased the pressure on land. Today there is considerable pressure to transform land into a commodity to be bought and sold in the market for non-agricultural purposes (D'Costa and Chakraborty

\footnotetext{
${ }^{1}$ While shorter follow-up visits were carried out between 2014 and 2017, the account is mostly based on data produced during 2007 to 2009.
} 
2017). This process is driven by India's contemporary economic development concerns that centre on industrialisation (Nielsen and Oskarsson 2017), infrastructure, special economic zones (Jenkins et al. 2014) and real estate expansion so that, rather than acting as a dynamic source of agrarian accumulation, land is increasingly commodified and directed towards nonagricultural development. The increased potential for rents, profit and accumulation in the fields of urbanisation, real estate, industrialisation and mining in turn drives the demand for land and pushes up prices (Chakravorty 2013; Sampat 2014).

The aggregate outcome has arguably been one of accelerating land dispossession and land commodification that has seen the control of considerable areas of land pass into the hands of the private sector. ${ }^{2}$ This process has, however, been an extremely contentious one that has triggered widespread resistance from dispossessed communities in many parts of India. As Kennedy $(2014,83)$ writes with reference to India's troubled Special Economic Zones (SEZ) policy that has seen upwards of 50,000 hectares of land pass into the hands of SEZ developers, there has been some form of protest in nearly every part of the country where SEZ projects have been proposed, and in many cases prolonged mobilisation. Contestations over land and its uses have thus multiplied (Bedi and Tillin 2015), as evidenced in a steadily growing literature on what is now often referred to as India's new land wars (Levien 2013a; Steur 2015; Nielsen 2016a; 2018; Nielsen and Bedi 2017). This literature has provided crucial insights into the making and operations of a new regime of dispossession in which the Indian state can increasingly been seen to facilitate the dispossession of smallholder farmers and indigenous groups to enable large-scale investments driven by private capital (Levien 2013b; 2018). It has also mounted a critique of the legal regime underpinning the state's exercise of eminent

\footnotetext{
${ }^{2}$ While 'the great Indian land grab' (Sud 2009; see also Basu 2007) may not appear quite as great, quantitatively speaking, when compared to the vast land transfers that have taken place in parts of Latin America and Africa (Borras Jr et al. 2012), the general tendency is clear enough.
} 
domain (Levien 2011; Sundar 2011; Ghatak and Ghosh 2011; Nielsen and Nilsen 2015; 2017), and has documented the considerable variation that exists across India's federal states, both in the modalities through which land has been acquired; the manner in which elites have sought to manage the potential fallouts of land dispossession (Bedi and Tillin 2015; Jenkins et al. 2014); as well as in the ways in which local communities have reacted when faced with the prospects of land dispossession. Indeed, as the rapidly growing literature on 'the global land grab' has shown us, political reactions 'from below' to dispossession have generally been vastly more varied and complex than is usually assumed in studies that place resistance and anti-dispossession politics at the centre of analysis, or which operate with homogenising notions of 'rural' or 'tribal' communities bereft of internal differentiation (Oskarsson 2017; Levien 2018). The fact that local communities - in India as elsewhere - are inherently socially differentiated means that different people will perceive and interpret processes of land dispossession differently, based on a whole range of variable and relative economic, political, social and cultural factors, conditions and calculations (Hall et al. 2015). We return later to examine how this internal differentiation - including, but not limited to, differentiation along the lines of caste, as also illustrated from other Indian contexts in Loraine Kennedy's (2019) and Ritanjan Das' (2019) articles in this special issue (see also Steur 2015) - shaped the social field in which movement leaders like Dipak Koley operated. But first the question of caste, power, and leadership needs to be addressed.

\section{Caste, Power and Leadership}

Discussions on power in agrarian societies tend to start from land. Land is co-determinative of access to political and economic resources and governs social, productive and reproductive relations through hierarchies of distinction and status within and between caste groups, 
households and genders. In India it was the pioneering rural anthropology and sociology produced during the heyday of village studies in the 1950s and 1960s that forcefully brought to our attention the intimate connection between caste, land and power. An important step in this direction had been made with the 1936 publication of William H. Wiser's (1988) monograph on the jajmani system, the philosophically and religiously sanctioned system of interrelatedness between caste groups, established through complex exchanges of goods and services. Although Wiser stressed the integrative and stabilising features of the jajmani system, his ability to relate the socio-political structure of a village to the distribution of land, wealth and income effectively opened up new spaces for investigating the operations of power in rural India.

Later generations of rural sociologists would expand on Wiser's work to stress the inherent class dimensions of the jajman-kamin (servant) relation, pointing out how the structures of patronage and dependency embedded in it quite evidently lent itself to the exploitation of the latter by the former. The basis of this exploitation was crucially centred on land ownership (Lewis and Barnouw 1956). Moreover, the nexus between land and power was very often embedded in caste. The jajman par excellence would typically, in Srinivas' (1959) memorable phrase, belong to 'the dominant caste' (Srinivas 1959) in a village, a caste which would be numerically strong and of a 'high' (Greenough 1980, 218) - or at least 'not too low' - ritual standing (see also Pocock 1962). I return to the discussion of the relationship between caste and class later.

Within this broader pattern, Greenough's $(1980 ; 1983)$ work on deltaic Bengal to the south and east of where the case study in this article is drawn from has specified the crucial role that the control of land - especially paddy land - has historically played in the formation of similar landlord-patronage relations. The traditional Bengali landlord-king, writes Greenough, was an annadata, a provider of subsistence - first and foremost rice and paddy land - to his 
subjects (Greenough 1983, 838). As such, land and the command of paddy and rice were 'the means of mastery' (Greenough 1983, 840; see also Greenough 1980) for gods, kings and masters of families alike. This bestowed upon those who controlled land the power to regulate the flow of rice from field to cooking pot through their expanded grip on tenancy, employment, wages, credit and charity (Greenough 1983, 845). Greenough's argument reflects the broader fact that the nexus between land, caste and power has historically been seen as a close one in rural Bengal. In the $19^{\text {th }}$ century the zamindars, the owners of the big estates or zamindaris, characteristically belonged to the high castes (Brahman, Kayastha and Baidya), whereas the jotedars (the village dominating landlords) were typically from traditional agricultural castes such as the Sadgop or Mahishya (Béteille 2007), to which Dipak Koley belonged. The overwhelmingly landless labourers or majur - such as those who inhabited contemporary Nadipara - in contrast, came from the 'untouchable' castes (Thorner 1991).

Yet since the late $19^{\text {th }}$ century things have been changing. In southwestern Bengal where the case that follows is set, a broad segment of middle-caste peasant smallholders, or ownercultivators, gradually emerged. The Mahishya caste that Dipak Koley belonged to was among the numerically most significant of such castes in what is sometimes referred to as 'the Mahishya belt' that runs through the districts of Howrah, Midnapore, and Hooghly where Singur is located. This segment would experience upward social mobility at the expense of the zamindars, and some acquired considerable clout and influence (Ruud 2003, 24-25; Majumder 2012). Livelihoods diversification also took place among this segment. New Mahishya entrepreneurs, for example, played an important role in the expanding small engineering sector in southern Bengal from the early $20^{\text {th }}$ century (Bandyopadhyay and Samaddar 2017) - and, they would almost exclusively employ their fellow caste members as workers, thus bringing into being a Mahishya blue collar working class. To consolidate their 
growing influence as a community the Mahishya organised their own caste society which brought out its own journal; and other caste organisations were formed to promote literacy, education, and 'women's reform' (Bandyopadhyay 2004).

The influence of the middle caste peasantry was further consolidated when post-independence land reforms did away with the zamindars at the top and eliminated whatever remained of the smallholders' relations of dependency on feudal lords. And, when a Communist-led government was elected to power - first in the late 1960s and again from 1977 onwards - the main beneficiaries of its subsequent land reforms and other rural policies would, perhaps ironically, be precisely this middle-peasant segment of middle-caste status. As shown by e.g. Bhattacharyya (2016), Majumder (2012), Mallick (1993), and Roy (2014, 193-215) the middle peasants generally benefited moderately from the state-led redistribution of agricultural land, and moved in to occupy local positions in the communist parties and their unions. The upper and middle peasantry would, in other words, often dominate the various tiers of the panchayat system of decentralised governance, as well as the left parties (Roy 2014, 40). Many also became school teachers and acquired the literacy and knowledge that enabled them to emerge as influential local mediators between villagers and the institutions of state and government (Bhattacharyya 2016). These were positions of considerable influence. From the 1970 s to around 2005 , political parties - and the communist parties in particular dominated the socio-political scene in rural West Bengal and penetrated deeply into the everyday lives of villagers, to the exclusion of most other mediating institutions (Bhattacharyya 2009; 2011; 2016). Meanwhile, the class that the governing left rhetorically claimed as its own, but actually kept at bay, was that of the socially and economically marginal agricultural workers.

Far-reaching historical transformations have thus changed the matrix of power in rural Bengal. Political organisations, parties, and popular endorsement have emerged as new sources and 
modalities of power and have partially rendered caste, land and economic status a much less secure, and much less exclusive, foundation of power and leadership. Indeed, according to Ruud (2016) the earlier clientilistic relationships of agricultural society are now gone and caste as a social indicator has considerably weakened. As a consequence, new types of leaders have emerged who rely less on personal sources of power derived from land and caste status, and more on contacts in the local state machinery and political parties, among businessmen, contractors, and brokers, etc. As Katy Gardner $(2012,40)$ writes from neighbouring Bangladesh, such contacts or 'connectivity' is vital in everyday village life across the larger Bengal region. In order to get hold of almost anything, Gardner writes, one has first to be connected to other people, whether they are located within the area, in state bureaucracies, or further afield. Power, Mosse $(2018,432)$ asserts, is thus manifested precisely in the capacity to connect: because things only get done through connections, those who hold the capacity to connect are repositories of power and figures of leadership.

The anthropologist Laura Bear $(2015,99-122)$ has discussed the practice of forming connections social relationships for productive purposes through the Bengali term jogajog kora, which literally means 'to do relationship', or 'to do connections'. By cultivating networks of relationships and connections that can be instrumentalised in the pursuit of shared goals - at least from time to time - people expand their horizon of influence and enhance their capacity to make things happen. Persons who can construct a broad assemblage of connections and contacts are, in turn, well positioned to emerge as persons who people seek out for help and assistance - a leader, in other words. In light of such arguments we can appreciate why the creative and entrepreneurial mixing of styles and genres that leaders draw on as they manage connections in the pursuit of a following is often highlighted as a defining characteristic in the literature on political leadership in South Asia (Price and Ruud 2010; Nielsen 2012). This literature helps us make sense of the ways in which movement leaders 
like Dipak Koley worked to cultivate and manage social relations and connections to energise the local anti-dispossession movement. To conceptualise this work, it is fruitful to approach it as the work of orchestration. The concept of orchestration has gained traction in the field of international relations and international law where it denotes a distinct mode of indirect and 'soft' governance (Abbott et al. 2012), but for the present purpose we draw on the more anthropological and sociological understanding (e.g. MacDonald 2010; Bennike 2017) that foregrounds the performative and processual aspects of orchestration. In a recent article on social movement activism, Battilana and Kimsey (2017) define activists who engage in building and sustaining an expansive network of relationships with constituents across groups, organisations, and sectors as 'orchestrators'. In contrast to their two other types of movement activists that they call 'agitators' and 'innovators', 'orchestrators' navigate a constant tension between tailoring their communication to the various constituencies they need to persuade without compromising on the overall message they work to convey.

The orchestration that 'orchestrators' work to achieve can be understood as the intentional act of organising individual elements of larger assemblages in such a way that those elements work towards a predefined goal (MacDonald 2010). This involves coordination and particularly the formation of durable connections that stretch across time and space (MacDonald 2010, 260). It also involves channelling interaction, scripting narratives, and configuring space in ways that enhance the likelihood of desired endpoints actually being reached. Such endpoints will vary across social formations and movements, but a common aim will be to encourage participants to think of themselves as part of a coherent group (ibid., 266). For orchestration to gain effect both an audience and a stage for articulation are thus required - an articulation that often, but not always, takes the form of the spectacle. Following Thomas Blom Hansen (2004), spectacles are more than just public events with spectacular qualities. They are generative political moments par excellence when public moods and 
sentiments - all those subjective and floating energies that animate politics and shape what people like and dislike (ibid., 20) - are generated. Orchestration through spectacle thus involves managing social and spatio-temporal relations in such a way that an audience is assembled and energised in a particular space at a particular time, and towards a given end.

This emphasis on the work of the individual, entrepreneurial orchestrator, however, should not lead us to lose sight of the broader social field in which such orchestrators operate. And in spite of Ruud's claims about the general weakening of caste and clientelism, this is a field where caste remains important. ${ }^{3}$ There is thus ample ethnographic evidence from West Bengal that demonstrates how caste continues to shape social relations and access to power and influence (see e.g. Roy 2012; 2014, 193-215; Samaddar 2013; Chandra et al. 2016). The Bengali upper castes, for example, remain disproportionately influential in the state legislative assembly across party lines (Lama-Rewal 2009) and tend to dominate the 'third space' of the NGO sector (Harrison 2017). Drawing on Bourdieu, Sarbani Bandyopadhyay (2016, 36-37) has explained this ability to reproduce caste power in new ways, and in shifting socio-political contexts, as a function of historically accumulated caste capital. Caste capital, she argues, may well have old roots, but can at the same time be made remarkably malleable to suit new institutional orders and opportunity structures. Comparably, elsewhere in this special issue Samantha Agarwal and Michael Levien (2019) analyse the endowment effect of historical caste-based inequalities to bring out how certain privileged castes manage to reproduce their dominance by virtue of the socio-material foundations they have built up over time. Importantly, when thus reworked as private connections and capital, caste advantage is not so easily perceived as such (Mosse 2018, 427). As will be argued later, it is in light of such arguments that we can appreciate how the Mahishya caste that Dipak Koley belonged to had

\footnotetext{
${ }^{3}$ As David Mosse (2018) has recently reminded us, current economic and political forces have - somewhat paradoxically - simultaneously weakened and revived caste in ways that defy easy generalisation.
} 
succeeded in consolidating the influence they had gradually acquired over the course of many decades, if not centuries. This consolidation and subsequent translation of caste into connections and capital (including social capital) in turn provided the springboard for individuals like to Dipak Koley to move into both institutionalised local party politics and popular anti-dispossession movements, while at the same time erasing the 'caste roots' of his influence.

The fact that orchestration occurs in a complex social field marked by caste offers us an important entry point for understanding how caste is implicated in the orchestration and leadership of anti-dispossession movements. As MacDonald (2010) argues, because orchestration and 'spectacular domination' are always incomplete, in the sense that staged spectacles never produce uniformly shared meanings among participants, they necessarily involve and produce dissent. This dialectic between orchestration and dissent thus opens a window into the ideological and material struggles that always occur within movements struggles that in the case of the anti-dispossession movement in Singur were, as will be shown later, partially structured around caste.

The two ethnographic cases below illustrate both these qualities associated with orchestration that have been outlined above: orchestration as intent and orchestration as dissent. The first focuses on a spectacle, namely the movement's first annual shahid divas, or martyrs' day. It brings to light the kind of orchestration of social relationships that go into energising antidispossession politics at the local level. Such orchestration, we argue, constitutes a key ingredient in what movement leaders - as 'orchestrators' - do when they lead. And, because this orchestration is intentionally geared towards creating and consolidating social relationships around a shared agenda and set of goals, it gives little indication of involving dissent. The second case, in contrast, shows how dissent is implicated in movement orchestration and the internal politics of the movement more broadly, along caste lines. It 
does so by taking seriously the proposition that orchestration stretches across the time and space of the spectacle. It therefore looks at the more routine and less spectacular sphere of movement politics to show how caste relations and tensions are negotiated. This brings to light a somewhat different, less benign, and more insidious modality of orchestration that is concerned with policing exclusionary caste boundaries, even as it claims to work towards achieving movement coherence and unity. Thus, while the first case shows how leadership is manifested in the capacity of individual orchestrators to 'connect', the second case shows how it is equally manifested in their capacity to curb the capacity of others to connect (see also Mosse 2018), even to actively 'disconnect' them.

While the caste dimensions are intentionally foregrounded in the two cases, this should not be read as a case for Indian exceptionalism where extra-economic distinctions along the lines of caste are seen as inherently more important than economic distinctions based on class. Rather, I conceptually follow Shah et al. (2017) in seeing caste, identity and class as inseparable.

Shah et al. use the notion of conjugated oppression to analyse how multiple axes of identitybased oppression, including caste, are constitutive of and shape class relations and are by necessity inseparable from each other. While Shah et al. foreground class as they tease out the prospects for class struggle in contemporary India, their argument that the idioms of class and caste may blend and combine in different ways in concrete political struggles is an important one that points to the inseparability of class and caste at the idiomatic and experiential level. Seeking to analytically holding together what holds together in practice, this inseparability in reproduced in the ethnography that follows. 'Caste' (i.e. Dalit, Bauri, Mahishya) and 'class' (khet majur, chasi) idioms are thus used interchangeably and sometimes in conjunction. 
The anti-dispossession movement that Dipak Koley led locally was not an easy movement to lead. It emerged in an impromptu manner as a response to news that came out in late May 2006 that a sizeable area of land was likely to be acquired from the Singur area and handed over to Tata Motors who would build a car factory on it. A local resistance committee - the Committee to Save the Farmland of Singur/Singur Krishi Jomi Raksha Committee (SKJRC) was formed on the spot as a non-party political organisation. It championed the one-point agenda of 'saving the farmland', i.e. preventing the land dispossession from going ahead, and symbolically centred its campaign and rhetoric on the figure of 'the unwilling farmer', that is, farmers who stood to be dispossessed of their land against their will. While the figure of 'the unwilling farmer' and its link to the question of caste is discussed in the second ethnographic case, it is worth stressing here that the movement in important ways conformed to Michael Levien's (2013b) generic approach to India's new anti-dispossession movements which generally emerge as spontaneous single issue people's movements. Levien's contention that such movements also tend to be cross-caste and cross-class movements similarly applies to the Singur movement, at least in its early stages. Described as a movement of small and marginal farmers, sharecroppers, and landless labourers (Roy 2014, 160-161), the Singur movement counted among its supporters middle-caste owner-cultivators of the Mahishya caste (such as Dipak Koley); some upper and middle caste salaried professionals from the Brahmin and Kayastha castes; Dalit labourers from the Bauri and Bagdi castes, many of whom lived in Nadipara; some backward caste Goalas in the traditional business of milk and cattle; and petty traders and workers of various castes, to mention just some.

Importantly, even if a tendency has been noted for agriculture-dependent households to be over-represented in the movement (Roy 2014; Ghatak et al. 2012), no rural classes or caste groups rallied behind the movement en bloc, nor did they oppose it en bloc. There was, in other words, no pre-existing caste solidarity that determined the ways in which villagers 
viewed and responded to the news of the land acquisition. Even in Dipak Koley's village of Shantipara which was considered one of the core centres of the anti-dispossession movement - and which was demographically dominated by the Mahishya - several Mahishya families had accepted the financial compensation they were entitled to and had relinquished their land. And, in other Mahishya dominated villages the balance between 'unwilling' and 'willing' farmers was more even, with the latter outnumbering the former in most places. Sometimes families were divided internally between relatives who wanted to hand over the land and those who wanted to resist dispossession (Majumder 2012; Majumder and Nielsen 2017).

Generational differences in life experience and aspirations constituted another axis of differentiation, albeit not in any uniform way. For intermediary agricultural castes such as the Mahishya, land ownership and cultivation have historically been important identity markers and a path towards upwards caste mobility, social status and respectability (Bandyopadhyay 2004), and among a section of the older Mahishya generation in Shantipara attachment to the land and to a chasi, or owner-cultivator, identity remained strong. While this chasi identity could be mobilised in defence of the farmland, among many younger men in the Singur area growing aspirations for more respectable and better paid off-farm work - such as that provided by Tata Motors and the auxiliary industries that it would bring along - had lessened these attachments. As a result, many entrepreneurial young men worked to position themselves to benefit economically from the coming of the Tata factory - though many of them simultaneously publicly denounced it (Majumder 2012; Nielsen 2017) - even as other groups of young men were convinced that the new industry would not provide them with jobs (Roy 2014, 171). Villages, neighbourhoods, caste groups, cohorts, and families were, in other words, divided on the issue of land dispossession - and even individuals could be in two minds about it (Majumder 2010). 
In much the same way, the two political parties that were locally influential saw internal divisions over the land acquisition. While sections of the local CPI(M) leadership worked hard to promote the Tata Motors project (Das 2016), the perceived 'anti-peasant' nature of the land acquisition (Roy 2014, 179) alienated many long-time CPI(M) supporters. Conversely, the main opposition party in the state at the time, the Trinamool Congress (TMC) that eventually came to spearhead the anti-dispossession movement ended up losing the support of some villagers who saw much-desired economic opportunities in the Tata factory. In other words, even if the local divide between the jami dewyar dale (the land-givers' group) and the jami na-dewyar dale (the non-givers' group) ran deep (Roy 2014, 184-185), this divide neither followed economic nor extra-economic fault lines in any clear-cut manner.

Movement leaders like Dipak Koley thus had to navigate this multitude of local fissures across the lines of caste, class, locality and party out of which the movement's social base was stitched together. It was to cement this heterogeneous base around the movement's one-point agenda and make supporters feel as part of a coherent group that movement leaders worked to orchestrate events and spectacles that would promote the identity of the movement, and define its members and opponents. An important part of this work involved orchestrating functioning connections to the multitude of other organisations, unions, political parties, and the media both local and non-local - that supported the Singur movement and provided important moral, material, discursive and logistical support that local movement leaders were keen to win and retain. To appreciate how this orchestration works we turn to the commemoration of the first annual shahid divas, or martyrs' day, that was held in December 2007 on a large field in Bajemelia to commemorate those SKJRC activists who had lost their life during the movement.

The planning for the shahid divas started only a few days prior to the event itself when the local leadership of the SKJRC met. Their discussion had centred on not just how to organise 
the shahid divas and make it successful, but also on how to host a group of urban intellectuals and artists from the Shilpi Sanskritik Karmi o Budhijibi Manch (SSKBM), the Forum for Artistes, Cultural Activists and Intellectuals, who had let the SKJRC know that they would like to visit Singur to show their support for the anti-dispossession movement. The SSKBM included many popular personalities of considerable cultural fame, and the SKJRC was keen on retaining and strengthening its connections with this forum that brought to the antidispossession movement considerable cultural and intellectual capital. The SSKBM, however, planned to visit Singur the day before the shahid divas. And organising two large events at such close intervals posed a logistical challenge to the SKJRC who depended on a limited number of local 'organisers' like Dipak Koley to make the necessary arrangements. While one SKJRC leader had suggested to invite the people of the SSKBM to attend the shahid divas as special VIPs rather than organising a separate programme for them the day before, this was not endorsed by the rest of the SKJRC. Nor was it discussed whether one should simply ask the SSKBM to come at a less busy time as this might have been interpreted as a refusal on the SKJRC's part to accept the SSKBM's public show of support for the movement, something which would have risked weakening the connection between the two. The SKJRC accordingly went ahead and organised a separate programme for the SSKBM the day prior to the shahid divas.

Over the next few days local SKJRC organisers were busy constructing a dais near a local bazaar in preparation for the SSKBM's visit. Microphones and a loudspeaker system were rented, large tarpaulins for the crowd to sit on were obtained, and tube lights mounted on and near the dais in the event that the visiting dignitaries decided to continue their meeting after nightfall. All of this required that certain local contacts be activated so that the right equipment could be obtained in time. It also required money. The production of spectacles can be expensive (see MacDonald 2010, 269), and for a dais and a loudspeaker system the 
SKJRC would need around INR 1,000. In addition they would need money for tea, tiffin and bottled water for the VIPs, and for other unforeseen expenses. In contrast to party political rallies during an Indian election campaign where the list of expenses is long and can include posters, billboards, vehicles for transport, polling agents, booth managers, food and shelter for campaign workers and 'hand-outs' to real and potential supporters (Vaishnav 2017, 139-140; Björkman 2014), the expenses associated with the SKJRC's event paled in comparison. Yet there were multiple other financial concerns that the SKJRC regularly needed to address, such as hiring lawyers to fight battles in court, or to pay for the medical treatment of injured movement activists. A financial issue that currently had to be dealt with urgently was that around 150 anti-dispossession activists who had 'bailable' cases pending against them now had to put up bail in order to avoid arrest. The SKJRC leaders accordingly planned for a fund raising drive at the local train stations, for which they would need to mobilise their local supporters and well-wishers.

The SKJRC also - with some apprehension - discussed the news that the SSKBM would bring along a bunch of blankets and other forms of 'emergency relief' to distribute among villagers who had fallen upon hard times after they had been dispossessed of their farmland. Not long ago, another urban activist group acting in solidarity with the movement had similarly come to Singur with a promise to distribute blankets among the needy. However, many recipients had been offended when they found out that the blankets were old and of poor quality. They had complained to Dipak Koley that it was offensive to be treated as 'beggars' and offered used rags in place of proper blankets - even if they had been dispossessed and were now poorer than before, they retained their dignity, they had protested. The situation was aggravated by the fact that the visiting activists had ostensibly insisted on distributing the blankets among movement supporters on their own accord and without consulting the local SKJRC leaders. Leaders like Dipak Koley claimed to keep track of who 
got what when emergency relief arrived in Singur to ensure that nobody was treated unfairly. By not consulting the local leadership prior to handing out the blankets, the visiting activists had offended many movement supporters who had been passed over when it had, in fact, been 'their turn' to benefit from the relief. While Dipak Koley had subsequently tried to explain to the disgruntled movement supporters that the wrongful distribution of blankets was unintentional, the risk that such events would create animosity and weaken relations between different groups of movement activists - between those who got too much and those who got nothing - was always there and had to be taken seriously.

The most important point on the agenda at the SKJRC meeting was, however, how to promote the shahid divas and ensure a large turnout. For this, the SKJRC needed to arrange for an auto and a battery-driven speaker system to drive through the villages in the days leading up to the event to encourage the villagers to attend. The SKJRC's president had brought up the idea of erecting a shahid bedi, a martyr's column or pulpit, in honour of the movement's 'martyrs'. The shahid bedi, he stressed, should be a proper one: since the purpose of the shahid divas was to honour the martyrs it might alienate the relatives of the martyrs - as well as devoted anti-dispossession activist who sometimes faced real physical danger - if the public memory of their sacrifice was materialised in a shahid bedi constructed in haste and from inferior materials. To show due respect, a candle light march to honour the movement's most prominent martyr, a teenage girl named Tapasi Malik, was also planned for.

With the programme in place, the discussion returned to the issue of how to mobilise as many people as possible to attend. Ensuring a large crowd was of the utmost importance for several reasons. Most obviously, because spectacles such as a shahid divas provides the crucial stage from which mobilising moods and sentiments are created, relationships and solidarity between movement supporters cemented, and loyalty to the common cause affirmed, it was crucial that people actually showed up. Conversely, a poorly attended rally would indicate 
dwindling support for the movement and might risk demoralising rather than energising those who attended. It would also reflect poorly both on the visiting political dignitaries and on local movement leaders like Dipak Koley whose influence was likely to be socially evaluated based on the turnout he could muster (see also Ruud 2001; Samuelsen 2017, 137-140). This time of year (December), however, the potato season had only just started and villagers would usually be busy tending to their fields. This meant that SKJRC leaders would need to make an extra effort to ensure a respectable turnout. One movement leader had suggested that they should work to make the local school students participate since this would ensure an attendance of several hundred youths. But the suggestion was dismissed since this was also the time of year when students should properly be busy studying - making students spend a full day at the shahid divas would therefore be very unpopular among both students and parents.

In the end it was agreed that one should not make arrangements that would inconvenience the movement's supporters, but rather work to encourage them to come of their own volition. To make attendance easier, the SKJRC organised the shahid divas between 3 and 5 pm: even if people were busy in their fields, most would be able to set aside a few hours this time of day, that is, after a full morning's work and lunch; and since it would be getting dark shortly after $5 \mathrm{pm}$, they could proceed straight to the candle light march. The programme, in other words, could be wrapped up successfully in just a couple of hours. It was also stressed that if any well-known artists - such as those in the SSKBM - were coming to the shahid divas to sing or read poetry, this should be actively used to promote the event.

A final issue that the SKJRC discussed was whether they should carry party political flags during the shahid divas. On the one hand, flags and banners added colour to the event, and the presence of many different party political flags at the same event would show not only that a large number of political parties in the state supported the movement, but also that the 
movement was able to transcend the party political divides that otherwise run very deep in rural Bengal. In other words, the presence of a multitude of different party political flags would symbolically illustrate to the crowd the extensive network of powerful party political connections that the movement had access to, as well as its leaders capacity for skilfully orchestrating these connections in ways that bridged otherwise deep differences. There was, however, no consensus on this issue among the leadership. One of the SKJRC's convenors who was also an activist of the Socialist Unity Centre of India (SUCI), a party on the nongovernmental left, objected that since the shahid divas was a SKJRC event - that is, a 'movement event' and not a 'party event' - it would be divisive to bring party political flags. Instead, he insisted that unity and the ability to transcend party differences were best orchestrated by having the different political parties laying aside their flags and coming together exclusively under the banner of the SKJRC. This suggestion was not readily endorsed by those SKJRC leaders who were affiliated with the TMC and who wanted to bring their party's flag to the event. Although nobody said so openly, it was well known to all that the TMC and its local activists played the leading role in the movement locally, and that if flags had been allowed at the shahid divas the TMC's party flag would have easily outnumbered those of all other supporting political parties combined. While this would have enabled the TMC to stake a symbolic claim to the shahid divas, it would likely have alienated movement supporters with competing political affiliations, as well as those movement activists who maintained that the movement should remain committed to its original nonparty political orientation. The SKJRC president eventually suggested an amicable compromise: people should be allowed to carry party political flags with them as they made their way to the venue; but once they had arrived, the flags should be rolled up and put aside for the duration of the shahid divas. 
As it were, Dipak Koley would have reason to be satisfied with both events. The visit of the SSKBM went well, and the shahid divas attracted a large crowd, not least because of the TMC's intra-party connections that had mobilised a number of youths from the party's district youth organisation to attend. Local SKJRC leaders acted as hosts, orchestrated the mood of the crowd through fiery speeches, and welcomed the visiting influential dignitaries that included politicians from many different parties who came to support the movement and speak of its national importance in raising new debates about land dispossession. This included the TMC's supreme leader, the flamboyant Mamata Banerjee, who pledged her unflinching loyalty to the movement and vowed to lead it to the bitter end. While Mamata Banerjee's arrival marked the 'dramaturgical climax' (Samuelsen 2017, 122) of the rally as the crowd erupted in cheers of 'Mamata Banerjee zindabad' (Long live Mamata Banerjee), neither she nor the many other political leaders and VIPs assembled on the stage had much to report about the anti-dispossession movement, its history, and its martyrs that was not already known locally. But, as Mukulika Banerjee (2014, 71-72) writes with reference to party political rallies in India, what is actually said in a speech is oftentimes of only secondary importance. What matters are not words but the spectacle as such. Here, the presence of important leaders and a large crowd - measured by the number of bodies physically present communicates first and foremost organisational strength and broad popular support. And, as MacDonald (2010, 268-269) similarly notes from the high-profile meetings of the World Conservation Congress, the presence of VIPs on stage communicates 'importance' and provides access to sources of material support and credibility that are desired by local leaders and activists for both organisational and personal reasons. It also often increases attendance insofar as people are more likely to show up at a rally if they sense that those speaking in fact have the power to act on what they say (Harrison 2017, 491). The media was also present in large numbers, and through a programme that combined entertainment, songs, poetry recitals, 
sorrowful speeches, fiery displays of anger, and the general excitement created by the presence of a powerful leader (Mamata Banerjee) who arrived under Z+ security cover and in a long convoy of cars, the shahid divas delivered what it intended: it energised the crowd; defined friends and enemies; proved to the crowd and the broader public that the movement had not lost its vitality; and that its network of powerful supporters and sympathisers was large and intact.

The visits of the SSKBM and the shahid divas bring out the importance of local movement leadership in orchestrating anti-dispossession politics at the village level. While this orchestration touches upon all three basic elements of political rallies in India, namely the performative (speeches, poetry), the visual-material (flags, symbols, decorations), and the spatial (on- and off-stage arrangements) (Samuelsen 2017, 108), the orchestration that goes into managing such generative events centres crucially on social relationships and connections. To make the events materialise, a bewildering array of logistical details had to be attended to, from organising light, sound, transportation, candles, and other equipment, as well as food, drinks and cash, and skilled carpenters to produce a good shahid bedi. Many such logistical challenges were handled by activating social connections and relationships. This included the challenge of finding the money to host the event and, importantly, to bail out soon-to-bejailed activists. Keeping movement activists out of jail was of the utmost importance: failing to do so would undermine the morale of activists who had to serve time, and also risked weakening the morale of other movement supporters, who might become reluctant to agitate if this was perceived as likely to lead to actual, long-term imprisonment.

At the same time, managing social relationships productively involved a good deal of what Arild Ruud (2003) in his ethnography of village politics in Bengal describes as fingerspitzengefühl, or 'fingertip feeling', on the part of movement leaders. In order not to alienate powerful sympathisers, the important culture personalities of the SSKBM were 
placated and provided with a separate half-day programme of their own, even if this entailed considerable extra work. And relationships between the movement and smaller allies such as the SUCI were maintained by the decision to partially 'ban' party political flags from the event. To show due respect to the movement's martyrs and their families - and, by extension, to demonstrate the strong bond that existed between the movement and its activists - the SKJRC leadership took care to ensure that the shahid bedi was 'proper', and that the candle light march would be conducted gracefully. The local SKJRC leadership also took steps to ensure that local sensibilities were not offended by a re-run of an earlier blanket distribution gone awry; or by school-going children or busy farmers feeling compelled to attend against their will.

In these respects, neither the shahid divas nor the SSKBM's visit were unique. They resembled so many other regular movement spectacles - including marches, rallies, cultural functions, and larger public meetings - where specific people needed to be brought together in a particular place for a particular duration so that an efficient articulation of movement agendas and goals could take place. The ongoing orchestration that goes into these spectacles centres crucially, as shown above, on connections and social relationships - relationships between different leaders of different political persuasion; relations between leaders, activists and supporters; relations between different groups of supporters; and between the locality and the parties and organisations that connect the locality to the world beyond. These spectacles by intent and design seek to project unity, shared interests, and group coherence and therefore tend to gloss over dissent and discontent. The following case, in contrast, shows how orchestration also involved the active suppression of dissent, the marginalisation of competing agendas, and the disconnect of certain individuals and groups. To show how caste is implicated in this mode of orchestration we shift to Nadipara, the Bauri-dominated village introduced in the opening vignette. The aim of doing so is not to offer a holistic account of the 
wider material and symbolic differences that obtained between the inhabitants of Nadipara and the Mahishya living nearby (see Nielsen 2016c), but rather to use the perspective from Nadipara as a point of entry for further unpacking the caste dimensions of movement orchestration.

\section{A View from Nadipara}

The inhabitants of Nadipara were all Dalits. The majority belonged to the Bauri caste while a few families were Bagdi. ${ }^{4}$ Apart from a handful of the village's approximately 80 households that had owned minuscule parcels of land prior to the land acquisition, the villagers were all landless. They worked as agricultural labourers on the land of local landowning farmers many of whom were Mahishya - or they leased land from them on a seasonal basis. Some had more regular sharecropping arrangements and many engaged in various kinds of menial, and usually seasonal, labour such as ferrying bricks, cement, or crops on cycle-vans. After the rollout of the NREGA scheme from 2006, under which 100 days of manual labour per year is to be made available by the local gram panchayat to all those who demand it, some villagers had succeeded in getting some work via this route. But because NREGA implementation was tardy at best, and because the Dalit were poorly connected to the local gram panchayat that issued the mandatory job cards required to get work under NREGA, the introduction of NREGA had made little difference to the everyday life of most villagers. They remained poor. In other words, in both Nadipara and in Dipak Koley's Mahishya-dominated village of Shantipara, the ability to diversify out of agriculture in ways that substantially improved the quality of life had thus - as is often still the case in rural India (Gupta 2014; Shah et al. 2017) - proven both caste and class dependent. Whereas many Mahishya families were now pluri-

\footnotetext{
${ }^{4}$ This section builds on Nielsen (2016b; 2016c).
} 
active in both the farm and off-farm economy and also wielded local political influence, the Dalit of Nadipara remained socially, economically and politically marginal.

After the news of the land acquisition broke in 2006, most of Nadipara's Dalits had come to support the anti-dispossession movement. Their stated reason for doing so was that the elimination of 1,000 acres of farmland from the local economy would deprive them of their primary source of income. As an agriculture-dependent village they had few alternatives to fall back on, and would have to travel great distances to look for alternative sources of work elsewhere (Sinha 2007). Yet while the Bauri of Nadipara could thus identify with the movement's one-point agenda they had most often, as the opening vignette indicates, found themselves occupying the role of movement foot soldiers who followed instructions but did not give them; who marched in rallies but did not lead them; and who attended meetings but did not plan then. When the SKJRC held its regular meetings to plan future events, chart out new strategies, or liaise with important non-local movement supporters, the Dalits from Nadipara were thus rarely represented. This effectively disconnected them from the wider assemblage of relationships that is crucial to the constitution of power and leadership.

Only when most key decisions had already been made elsewhere were they conveyed to Nadipara through gram baithak, or informal village meetings. Even though such meetings took place in Nadipara they were routinely convened and led by movement leaders from Shantipara who would drive up to Nadipara, convey the relevant news and give instructions, and then leave again. Seen from Nadipara, then, the movement that they supported had an internal core-periphery structure (see also Nilsen 2010) that positioned the Mahishya and other movement leaders of middle or high caste status at the core, and pushed the Dalits to the periphery. On the one hand, as the opening vignette shows this core-periphery structure was based in part on caste stereotypes of the Bauri as hot-headed, irrational, and uneducated 
shirkers prone to drinking and quarrelling that made them unfit for leadership. ${ }^{5}$ On the other hand, this core-periphery structure was reinforced by the material conditions under which the Bauri lived, and their relative impoverishment. Because movement leadership is built on the ability to manage and orchestrate social relations it entails a high degree of mobility. Actual and potential supporters need to be visited, news gathered and conveyed, crowds assembled and addressed, and influential non-local supporters sought out and won over. This, in turn, requires both time and money, neither of which was available to the inhabitants of Nadipara on a sufficient scale.

The feeling of being pushed to the periphery generated a good deal of resentment among some Dalit movement supporters. One of them was Ajay, a man in his late twenties who acted as a point of liaison between Nadipara and the SKJRC leadership. While being placed at the periphery entailed being disconnected from the network of social relationships through which power was produced and manifested, it also had material consequences insofar as it entailed, in Ajay's experience, not receiving 'a fair share' of the relief that often poured in to the Singur area, most of which he claimed was diverted to middle peasant, middle caste households. And, importantly, it meant symbolic and discursive marginalisation. The movement's official one point agenda was to 'save the farmland' and restore it to the 'unwilling farmer', who functioned as the movement's crucial symbolic point of reference. However, as Ajay would point out, the Dalits of Nadipara had never had any farmland, nor had they ever been 'farmers' in the way in which the term is popularly understood, namely as an owner-cultivator. Ajay thus found it somewhat ironic that he, as a landless labourer who had never owned land in his life, should take part in an ongoing movement orchestration

\footnotetext{
${ }^{5}$ This stereotyping and the core-periphery movement structure it gave rise to echoes the bhadralok-chhotolok distinction, the social distinction between genteel people and 'small people' that to a large extent represents the traditional caste stratification in rural West Bengal (Roy 2014, 200).
} 
where he would find himself marching in rallies shouting slogans that demanded 'the return of the farmland' to 'the unwilling farmers', or that stressed how the locals 'would never give up their land' - where did the landless labourers who had no land to lose in the first place figure in this equation? Ajoy would ask.

As seen from Nadipara, land restitution, or 'saving the farmland', would in itself not make much difference. Only if land restitution also led to a resumption of cultivation on a scale that would recreate lost employment opportunities would the Dalits benefit from it. What was at stake for the Dalits who supported the movement was thus first and foremost the acute lack of local work opportunities that the land dispossession had created. Hence, while the Dalits could subscribe to the long-term one-point agenda of saving the farmland, there was a felt need to expand the agenda to also include other, more pressing short-term goals, Ajay felt. This could, for example, be done by raising demands for a stipend from the government for the landless labourers effective immediately, or for a guarantee of 200 days of work per year. Yet while he had from time to time raised this issue with the movement leadership it had not had the desired impact beyond verbal reassurances that it would be 'looked into'. For this reason, when one of the smaller constituents of the SKJRC - the Workers' Revolutionary Council/Majur Kranti Parishad (MKP) - floated the idea of setting up a semi-autonomous association to forward the interests of the landless within the SKJRC, Ajay and some of his fellow villagers responded positively. The new association was called the Association of the Affected Sharecroppers and Landless Labourers of Singur/Singur Akranta Bargadar Khet Majur Samiti (SABKMS), an explicitly class-based platform whose local target constituency were overwhelmingly Dalits. The SABKMS would work to raise the demand for a monthly stipend for the landless; for guaranteed work to be provided; for better implementation of NREGA; and for more attention to be paid to the particular needs and desires of the landless in the movement's overall campaign. 
To reach out to its target constituency SABKMS workers - including Ajay - started to connect with villages in the area to 'take the name' of locals supportive of their cause. In doing so, the SABKMS also sought to 'raise the consciousness' of the landless Dalits by encouraging them to critically reflect on their role in the anti-dispossession movement so far and in the local society and economy more generally. Was it fair that they, as landless labourers, should rally behind a one-point agenda that exclusively concerned itself with foregrounding the claims of the landowners? Would the Dalits even benefit from land restitution? And why was the middle caste chasi leadership seemingly so reluctant to broaden its agenda to include the demands of the poor, low caste and landless? By encouraging reflections such as these the SABKMS activists sought to bring out how the generic mobilising figure of the 'dispossessed unwilling farmer' with reference to which much of the movement's orchestration sought to foster feelings of group coherence was, in fact, crucially marked by caste and class. ${ }^{6}$ The SABKMS's and MKP's efforts to foreground a distinct Dalitkhet majur perspective on the anti-dispossession movement thus in effect brought to light important material, ideological, and caste-class anchored tensions that existed within the movement - tensions that are similarly visible in Kennedy's (2019) article in this issue - in spite of its leaders' efforts at rendering them invisible through orchestration and spectacle.

When I later spoke to Dipak Koley about his view of the SABKMS he did not formally criticise its agenda, he only emphasised the need for movement unity. It was fine if the landless Dalits wanted to raise additional demands that pertained to their specific situation, he explained, only they should have done so through the SKJRC in order to not fragment and weaken the movement by creating a new association and, by extension, by effectively

\footnotetext{
${ }^{6}$ While it may be argued that the MKP activists were instrumental in mobilising the Bauri behind the SABKMS, it is more accurate to see them as performing the kind of catalytic work (Nilsen 2010, 63-68) that enables rather than creates new forms of subaltern mobilisation.
} 
dividing it along caste and class lines. In this way, Dipak Koley rendered the Dalits the purveyors of caste politics, while he and other dominant caste leaders in contrast would stake claims to leadership on the grounds of personal qualifications, knowledge of 'the methods', and individual 'merit' in ways that obscured their origins as caste capital. ${ }^{7}$

Dipak Koley was also upset about what he saw as a betrayal of sorts by the MKP, who had worked as the catalyst for the emergence of the SABKMS. True to his style of managing connections and social relationships for productive use Dipak Koley had, he said, gone to great lengths to accommodate the MKP within the anti-dispossession movement in order to keep it united and strong. Compared to Dipak's own party, the TMC, the MKP was a small player in the larger movement, he correctly pointed out. But in spite of this he had, he claimed, tried to make space for them and their activists within the movement so as to maintain the broad 'rainbow alliance' of parties and organisations that constituted its extended - and influential - network of relations. Not only had MKP now via the SABKMS openly raised what Dipak Koley saw as a hugely divisive issue - it also seemed to him as if the MKP was covertly trying to establish itself as a political party in Nadipara which was otherwise TMC's turf and the inhabitants its vote bank. The emergence of the SABKMS and the MKP's work in Nadipara thus constituted a triple threat: it threatened to fragment the movement's network of connections; by doing so, it threatened Dipak Koley's personal status as an efficient movement orchestrator; and, by threatening to disconnect Nadipara from Dipak Koley's party the TMC it threatened to undermine his standing as a local political leader. Moreover, by encouraging Bauri assertion the SABKMS arguably also threatened to destabilise local intercaste relations in ways that might potentially undermine the social and political dominance of the middle (and upper) castes.

\footnotetext{
${ }^{7}$ See also Mosse (2018) and Subramanian (forthcoming) for comparable observations in other contexts.
} 
To deal with the challenge emanating from the SABKMS Dipak Koley met with Ajay several times to reassure him that the demands of the Dalits would from now on be given greater recognition by the SKJRC leadership. He also reminded Ajay that it was because of the antidispossession movement that Dipak Koley led that Ajay had now become 'a big man' in Nadipara. Whenever organisations such as the SSKBM came to Singur and asked to meet some of the landless labourers who had been adversely affected by the land acquisition, Dipak Koley had sent them to meet Ajay. In this way, Ajay had been at least partially connected to those wider social relationships in and through which leadership is formed. Dipak Koley offered to further extend Ajay's network by offering him a seat on a local school committee and other similar committees.

While Dipak Koley thus sought to orchestrate movement coherence by placating and 'connecting' Ajay, and agreeing to incorporate his demands in the movement, he simultaneously - according to Ajay - sought to discredit, marginalise and 'disconnect' him. Ajay found that rumours about him started circulating locally. Rumours that claimed that Ajay had become a Maoist, or that he had been bribed by Tata Motors to wreck the antidispossession movement from within by raising divisive issues, and by weening away Nadipara from the movement. When Ajay went to villages in the area to inform the locals about the SABKMS and their work, he would often see a chasi leader from the SKJRC lingering on his motorbike in the background. He suspected that his movements were being monitored, and that those who monitored him would try to turn the locals against him. For example, when he called villagers to SABKMS meetings many of those who had earlier told him that they would attend failed to show up, and Ajay claimed to have heard that the SKJRC leadership had actively gone around and told people not to stay away from Ajay's divisive 'Maoist meetings'. Threats had been made to people, Ajay said, even if they had been made in covert ways. Personally, he had been called to meetings with the SKJRC leadership at late 
hours, but had tried to avoid going for fear of being beaten up or otherwise punished for his insubordination.

The ways in which Dipak Koley sought to deal with the discontent among some of Nadipara's Dalits thus mixed incorporation, adaptation and co-optation with overt and covert forms of surveillance, threats, and exclusion. While his attempts at broadening the movement's set of demands and co-opting Ajay into its structure may be read as an instantiation of an orchestrator's ongoing delicate work of 'tailoring their communication to the various constituencies they need to persuade without compromising on the overall message they work to convey', as Battilana and Kimsey (2017) put it, Dipak Koley's 'tailoring of communication' evidently also relied on subtle threats and the manipulation of public sentiments through rumour and gossip so as to marginalise and exclude assertive Dalits. In effect, Dipak Koley's orchestration creatively drew simultaneously on the attraction of his capacity to connect others (Ajay) to wider networks, and the fear of his power to curb the ability of others (Nadipara's assertive Dalits in general) to connect (see also Mosse 2018, 432). This orchestration was thus a good deal less benign than what Battilana and Kimsey might have expected from an orchestrator, even if it was certainly no less creative and entrepreneurial. At the same time, 'not compromising on the overall message' was hardly the only driving force behind Dipak Koley's mode of dealing with dissent. At stake was also his personal reputation as a movement leader; his local standing as a TMC politician; and, not least, the broader structuring of local relationships between the middle caste Mahishya and the Dalits where the Mahishya, in his view, belonged at the core and the Dalit at the periphery.

After half a year or so, the SABKMS practically ceased to function. Unable to orchestrate and establish durable relationships with individuals and communities outside Nadipara, the SABKMS remained a marginal group that could mobilise neither resources nor followers to any great extent. And, with no influential party activists present in the villages in Singur, the 
MKP was unable to connect to those local social relationships that might have allowed it to establish itself as a political party in the area. After some time, Ajay thus let the SABKMS flounder. Dipak Koley, in contrast, exchanged his career as a movement leader for a career in party politics. He went on to be elected to the zilla parishad - the district level of West Bengal's decentralised local governance structure - and was included in the TMC's district party committee, thus further expanding his personal web of connections beyond the locality.

\section{Conclusion}

Movement leaders are clearly important for the organisation and maintenance of antidispossession movements. As orchestrators they repeatedly enable and stage public spectacles, work to energise fellow activists and forge loyalty to a common cause, and encourage people to see themselves as part of a coherent group (MacDonald 2010). In this context, the ability to productively orchestrate a broad assemblage of connections and social relationships has been shown to be of key importance. To make spectacles happen resources must be mobilised through extended networks, crowds assembled, influential representatives brought in, and visual, spatial, and symbolic arrangements managed. In these respects, the work of antidispossession movement leaders resembles that of other real and aspiring political leaders in India, who draw eclectically and creatively on different registers and repertoires of political action to mobilise a following in the pursuit of power and influence (Price and Ruud 2010; Samuelsen 2017). Yet, the particularities of orchestrating a broad-based, non-party political, and only loosely institutionalised 'rainbow' anti-dispossession movement with a one-point agenda poses specific challenges for orchestrators in terms of managing relationships between different leaders with different viewpoints, ambitions, and ideological orientations, as well as between different groups of supporters, both local and non-local. Given the heterogeneous 
and fragile nature of the movement's social base, the orchestration and projection of unity and shared commitment to a common cause was by definition ongoing and challenging work that required creative responses.

While the orchestration carried out by movement leaders as described in this article appears to hinge primarily on the mastery of a certain set of skills, or fingerspitzengefühl, which may be acquired over the cause of a political life and irrespective of social position, local caste-class relations crucially influenced who could lead and who could not. On the one hand, the caste background of movement the leaders mattered insofar as movement leaders were often drawn from the middle caste peasantry that had both acquired considerable local power over many decades and who - because they owned land - had themselves experienced direct land dispossession as a result of the Tata Motors project. While this ability of locally dominant castes to move in to occupy positions of leadership in new political formations is a reflection of the kind of endowment effects of historical caste-based inequalities that Agarwal and Levien (2019) analyse elsewhere in this special issue - of concealed caste advantage, in other words (Mosse 2018, 242) - such endowments are not just material but also eminently social: they consisted, among other things, of extended social networks as well as the capacity to creatively and productively orchestrate such networks in expansive ways; and a flair (underpinned by authority) for both connecting and disconnecting different individuals and groups.

The Bauri of Nadipara, on the other hand, had neither local influence nor extended networks that could be productively drawn on. Indeed, whatever relationships the largely poor, landless and underemployed Bauri had with other villages, institutions or organisations tended to be relations of dependency that offered at best only severely restricted scope for the kind of orchestration that underpins movement leadership. This situation led to a form of triple disconnect of the Bauri: disconnect from the movement's leadership circles, from its extended 
network of contacts and relationships, and from its discursive and symbolic registers as articulated in movement spectacles. This disconnect and marginalisation was reinforced by a mix of co-optation, incorporation, real and perceived intimidation, and the manipulation of public sentiments through rumour and gossip whenever the middle caste leadership failed to orchestrate unity through spectacle.

The different political careers of Dipak and Ajay are indicative of a broader pattern identified in this special issue where land dispossession is refracted through local caste-class relations in ways that tend to reproduce pre-existing inequalities, albeit in an uneven manner. While Dipak successfully used the movement to cultivate and enlarge his social and political network well beyond the locality and enhanced both his formal and informal power, Ajay's attempts at establishing productive relationships with new organisations soon floundered. Tellingly, on my latest visit to Singur in 2017 I found that Dipak, who remained an important TMC-leader in the locality, had built a large new house for himself and had seen to it that the dirt track that ran through his hamlet was now a pucca tarmac road. Ajay, in contrast, had no strong links with any local organisations or parties and worked irregularly on different NREGA projects and complained about delayed wage payments and complicated NREGArelated paperwork at the local panchayat office. ${ }^{8}$ Thus, while anti-dispossession movements do have the potential to evolve in unexpected ways that may challenge everyday caste, class and gender relations (Nilsen 2010; Nielsen 2018), this had occurred only to a limited extent in Nadipara. Dipak and Ajay's different trajectories thus show how the potential for and benefits associated with anti-dispossession activism in terms of connections, social networks, productive relationships, and political power are unevenly distributed along lines of caste and

\footnotetext{
${ }^{8}$ In material terms, the Singur movement had led to improvements in Ajay's life as more resources were now channelled towards Nadipara by the local gram panchayat that was now controlled by erstwhile movement activists and supporters.
} 
class. The fact that the ability to cultivate and appropriate the new political spaces opened up by the anti-dispossession movement thus correlated strongly with historically produced casteclass relations raises complicated questions about the ability of such movements to effect social transformation and calls for greater attention to the internal caste-class politics of antidispossession movements.

\section{Acknowledgements}

The author would like to thank the following for constructive input: Siddharth Sareen, Patrik Oskarsson, Guro W. Samuelsen, Alf G. Nilsen, Lisa Björkman, Kevin Hewison, the Oslo South Asia Symposium, the members of the 'dependency' research group at the Department of Social Anthropology, University of Oslo, and the Journal of Contemporary Asia's anonymous reviewer.

\section{References}

Abbott, Kenneth W., Philipp Genschel, Duncan Snidal, and Bernhard Zangl. 2012.

Orchestration: Global Governance through Intermediaries. https://ssrn.com/abstract=2125452 (accessed 19 January 2018).

Agarwal, Samantha and Michael Levien. 2019. Dalits and Dispossession: A Comparison. Journal of Contemporary Asia.

Bandyopadhyay, Ritajyoti and Ranabir Samaddar. 2017. Caste and the Frontiers of PostColonial Capital Accumulation. In Accumulation in Post-Colonial Capitalism, edited by Iman Kumar Mitra, Ranabir Samaddar and Samita Sen, 189-214. Singapore: Springer. 
Bandyopadhyay, Sarbani. 2016. Another History: Bhadralok Responses to Dalit Political Assertion in Colonial Bengal. In The Politics of Caste in West Bengal, edited by Uday Chandra, Geir Heierstad and Kenneth Bo Nielsen, 35-59. New Delhi: Routledge

Bandyopadhyay, Sekhar. 2004. Culture and Hegemony: Social Dominance in Colonial Bengal. New Delhi: Sage.

Banerjee, Mukulika. 2014. Why India Votes? London: Routledge.

Basu, Pranab Kanti. 2007. Political Economy of Land Grab. Economic and Political Weekly 42 (14): 1281-1287.

Battilana, Julie and Marissa Kimsey. 2017. Should You Agitate, Innovate, or Orchestrate? Stanford Social Innovation Review, 18 September,

https://ssir.org/articles/entry/should_you_agitate_innovate_or_orchestrate (accessed on 19 January 2018).

Bear, Laura. 2015. Navigating Austerity: Currents of Debt Along a South Asian River. Stanford: Stanford University Press.

Bennike, Rune. 2017. Frontier Commodification: Governing Land, Labour and Leisure in Darjeeling, India. South Asia 40 (2): 256-271.

Bhattacharyya, Dwaipayan. 2009. Of Control and Factions: The Changing 'Party-Society' in Rural West Bengal. Economic and Political Weekly 44 (9): 59-69.

Bhattacharyya, Dwaipayan. 2011. Party Society, its Consolidation and Crisis: Understanding Political Change in West Bengal. In Theorizing the Present: Essays for Partha Chatterjee, edited by Anjan Ghosh, Tapati Guha-Thakurta and Janaki Nair, 226-50. New Delhi: Oxford University Press. 
Bhattacharyya, Dwaipayan. 2016. Government as Practice: Democratic Left in a

Transforming India. New Delhi: Cambridge University Press.

Bedi, Heather P. and Louise Tillin. 2015. Inter-state Competition, Land Conflicts and Resistance in India. Oxford Development Studies 43 (2): 194-211.

Béteille, André. 2007. Marxism \& Class Analysis. New Delhi: Oxford University Press.

Björkman, Lisa. 2014. 'You can’t buy a Vote': Meanings of Money in a Mumbai Election. American Ethnologist 41 (4): 617-634.

Borras Jr, Saturnino M., Jennifer C. Franco, Sergio Gómez, Cristóbal Kay and Max Spoor. 2012. Land grabbing in Latin America and the Caribbean. Journal of Peasant Studies 39 (3/4): 845-872.

Chakravorty, Sanjoy. 2013. The Price of Land: Acquisition, Conflict, Consequence. New Delhi: Oxford University Press.

Chandra, Uday, Geir Heierstad and Kenneth Bo Nielsen, eds. 2016. The Politics of Caste in West Bengal. New Delhi: Routledge.

D’Costa, Anthony P. and Achin Chakraborty, eds. 2017. The Land Question in India: State, Dispossession, and Capitalist Transition. New Delhi: Oxford University Press.

Das, Ritanjan. 2016. The Politics of Land, Consent, and Negotiation: Revisiting the Development-Displacement Narratives from Singur in West Bengal. Samaj 13: 1-20.

Das, Ritanjan. 2019. Narratives of the Dispossessed and Casteless: Politics of Land and Caste in Rajarhat, West Bengal. Journal of Contemporary Asia.

Gardner, Katy. 2012. Discordant Development: Global Capitalism and the Struggle for Connection in Bangladesh. London: Pluto Press. 
Ghatak, Maithreesh and Parikshit Ghosh. 2011. The Land Acquisition Bill: A Critique and a Proposal. Economic and Political Weekly 46 (41): 65-72.

Ghatak, Maitreesh, Sandip Mitra, Dilip Mukherjee and Anusha Nath. 2012. Land Acquisition and Compensation in Singur: What Really Happened? Working paper. Boston: Institute for Economic Development, Boston University.

Greenough, Paul R. 1980. Indian Famines and Peasant Victims: The Case of Bengal in 194344. Modern Asian Studies 14 (2): 205-35.

Greenough, Paul R. 1983. Indulgence and Abundance as Asian Peasant Values: A Bengali Case in Point. Journal of Asian Studies 42 (4): 831-50.

Gupta, Dipankar. 2014. From Poverty to Poverty: Policies for Translating Growth into Development. In Persistence of Poverty in India, edited by Nandini Gooptu and Jonathan Perry, 129-145. New Delhi: Social Science Press.

Hall, Ruth, Marc Edelman, Saturnino M. Borras Jr, Ian Scoones, Ben White and Wendy Wolford. 2015. Resistance, acquiescence or incorporation? An introduction to land grabbing and political reactions 'from below'. Journal of Peasant Studies 42 (3/4): 467-488.

Hansen, Thomas Blom. 2004. Politics as Permanent Performance: The Production of Political Authority in the Locality. In The Politics of Cultural Mobilization in India, edited by John Zavos, Andrew Wyatt and Vernon Hewitt, 19-39. New Delhi: Oxford University Press.

Harrison, Tom. 2017. NGOs and Personal Politics: The Relationship between NGOs and Political Leaders in West Bengal, India. World Development 98: 485-496.

Jenkins, Rob, Loraine Kennedy and Partha Mukhopadhyay, eds. 2014. Power, Policy and Protest: The Politics of India's Special Economic Zones. Oxford: Oxford University Press. 
Kennedy, Loraine. 2014. The Politics of Economic Restructuring in India. London: Routledge.

Kennedy, Loraine. 2019. The politics of land acquisition in Haryana: Managing dominant caste interests in the name of development. Journal of Contemporary Asia.

Lama-Rewal, Stephanie Tawa. 2009. The Resilient Bhadralok: A Profile of the West Bengal MLAs. In Rise of the Plebeians? The Changing Face of Indian Legislative Assemblies, edited by Christophe Jaffrelot and Sanjay Kumar, 361-92. New Delhi: Routledge.

Levien, Michael. 2011. Rationalising Dispossession: The Land Acquisition and Resettlement Bills. Economic and Political Weekly 46 (11): 66-71.

Levien, Michael. 2013a. Regimes of Dispossession: From Steel Towns to Special Economic Zones. Development and Change 44 (2): 381-407.

Levien, Michael. 2013b. The Politics of Dispossession: Theorizing India’s 'Land Wars'. Politics and Society 41 (3): 351-94.

Lewis, Oscar and Victor Barnouw. 1956. Caste and Jajmani System in a North Indian Village. Scientific American 83: 66-81.

MacDonald, Kenneth Iain. 2010. Business, Biodiversity and New 'Fields' of Conservation: The World Conservation Congress and the Renegotiation of Organisational Order. Conservation and Society 8 (4): 256-275.

Majumder, Sarasij. 2010. The Nano Controversy: Peasant Identities, the Land Question and Neoliberal Industrialization in Marxist West Bengal, India. Journal of Emerging Knowledge on Emerging Markets 2, Article 5. 
Majumder, Sarasij. 2012. 'Who Wants to Marry a Farmer?' Neoliberal Industrialization and the Politics of Land and Work in Rural West Bengal. Focaal: Journal of Global and Historical Anthropology 64: 84-98.

Majumder, Sarasij and Kenneth Bo Nielsen. 2017. 'Should the Son of a Farmer Always Remain a Farmer?' The Ambivalence of Industrialisation and Resistance in West Bengal. In Industrialising Rural India: Land, Policy, and Resistance, edited by Kenneth Bo Nielsen and Patrik Oskarsson, 63-82. London: Routledge.

Mallick, Ross. 2007. Development Policy of a Communist Government: West Bengal since 1977. Cambridge: Cambridge University Press.

Mosse, David. 2018. Caste and Development: Contemporary Perspectives on a Structure of Discrimination and Advantage. World Development 110: 422-436.

Nielsen, Kenneth Bo. 2012. 'An Activist can’t become a Politician': Social Activism, Leadership and the (Un)making of a Political Career in an Indian State. Contemporary South Asia 20 (4): 435-53.

Nielsen, Kenneth Bo. 2016a. The Everyday Politics of India's 'Land Wars': A View from Rural Eastern India. Focaal: Journal of Global and Historical Anthropology 75: 105-118.

Nielsen, Kenneth Bo. 2016b. The Politics of Caste and Class in Singur's Anti-Land Acquisition Struggle. In The Politics of Caste in West Bengal, edited by Uday Chandra, Geir Heierstad and Kenneth Bo Nielsen, 125-46. New Delhi: Routledge.

Nielsen, Kenneth Bo. 2016c. Managing 'Communities’ of Resistance: Negotiating Caste and Class in an Anti-Land Acquisition Movement in West Bengal. In Staking Claims: The Politics of Social Movements in Contemporary Rural India, edited by Uday Chandra and Daniel Taghioff, 165-199. New Delhi: Oxford University Press. 
Nielsen, Kenneth Bo. 2018. Land Dispossession and Everyday Politics in Rural Eastern India. London: Anthem Press.

Nielsen, Kenneth Bo and Alf Gunvald Nilsen. 2015. Law-Struggles and Hegemonic Processes in Neoliberal India: Gramscian Reflections on Land Acquisition Legislation. Globalizations 12 (2): 203-16.

Nielsen, Kenneth Bo and Alf Gunvald Nilsen. 2017. Law-Struggles, Law-Making and the Politics of Hegemony in Neoliberal India: Towards a Critical Perspective on the 2013 Land Acquisition Act. In The Land Question in India: State, Dispossession, and Capitalist Transition, edited by Anthony P. D’Costa and Achin Chakrabarty. New Delhi: Oxford University Press.

Nielsen, Kenneth Bo and Patrik Oskarsson, eds. 2017. Industrialising Rural India: Land, Policy and Resistance. London: Routledge.

Nielsen, Kenneth Bo and Heather Plumridge Bedi. 2017. The Regional Identity Politics of India's New Land Wars: Land, Food, and Popular Mobilisation in Goa and West Bengal. Environment and Planning A: Government and Policy 49 (10): 2324-2341.

Nilsen, Alf Gunvald. 2010. Dispossession and Resistance in India: The River and the Rage. London: Routledge.

Oskarsson, Patrik. 2017. Diverging Discourses on Bauxite Mining in in Eastern India: LifeSupporting Hills for Adivasis or National Treasure Chests on Barren Lands? Society and Natural Resources 30 (8): 994-1008.

Pocock, David. 1962. Notes on Jajmani Relationships. Contributions to Indian Sociology 4: 78-95. 
Price, Pamela and Arild Engelsen Ruud, eds. 2010. Power and Influence in India: Bosses, Lords and Captains. New Delhi: Routledge.

Roy, Dayabati. 2012. Caste and Power: An Ethnography in West Bengal, India. Modern Asian Studies 46 (4): 947-74.

Roy, Dayabari. 2014. Rural Politics in India: Political Stratification and Governance in West Bengal. Delhi: Cambridge University Press.

Ruud, Arild Engelsen. 2001. Talking Dirty about Politics: A View from a Bengali Village. In The Everyday State and Society in Modern India, edited C. J. Fuller and Véronique Bénéï, 115-36. London: Hurst \& Company.

Ruud, Arild Engelsen. 2003. Poetry of Village Politics: The Making of West Bengal's Rural Communism. New Delhi: Oxford University Press.

Ruud, Arild Engelsen. 2016. From Client to Supporter: Economic Change and the Slow Change of Social Identity in Rural West Bengal. In The Politics of Caste in West Bengal, edited by Uday Chandra, Geir Heierstad and Kenneth Bo Nielsen. New Delhi: Routledge. Samaddar, Ranabir. 2013. Whatever has happened to Caste in West Bengal? Economic and Political Weekly 48 (36): 77-79.

Sampat, Preeti. 2014. Right to Land and the Rule of Law. PhD dissertation, City University of New York.

Samuelsen, Guro Warhuus. 2017. Performing Politics: The Making of Leaders and Followers in the Bahujan Samaj Party, Uttar Pradesh. PhD dissertation, University of Oslo. 
Shah, Alpa, Jens Lerche, Richard Axelby, Dalel Benbabaali, Brendan Donegan, Jayaseelan Raj and Vikramaditya Thakur. 2017. Ground Down by Growth: Tribe, Caste, Class and Inequality in Twenty-first-century India. London: Pluto Press.

Sinha, Kuver. 2007. Singur: Losses Beyond Compensation. Kolkata: Manthan Samayiki Publication.

Srinivas, M. N. 1959. The Dominant Caste in Rampura. American Anthropologist, NS 61 (1): $1-16$.

Steur, Luisa. 2015. Theorizing Thervoy: Subaltern Studies and Dalit Praxis in India's Land Wars. In New Subaltern Politics: Reconceptualizing Hegemony and Resistance in Contemporary India, eds Alf G. Nilsen and Srila Roy, 177-201. Delhi: Oxford University Press.

Subramanian, Ajantha. Forthcoming. Merit and Caste in Contemporary India: Producing Upper Casteness at the IITs. In Indian Democracy at 70: Origins, Trajectories, and Contestations, edited by Alf Gunvald Nilsen, Kenneth Bo Nielsen and Anand Vaidya. London: Pluto Press.

Sud, Nikita. 2009. The Indian State in a Liberalizing Landscape. Development and Change 40 (4): 645-665.

Sundar, Nandini. 2011. The Rule of Law and the Rule of Property: Law-Struggles and the Neo-Liberal State in India. In The State in India after Liberalization: Interdisciplinary Perspectives, edited by Akhil Gupta and K. Sivaramakrishnan, 175-93. London: Routledge. Thorner, Daniel. 1991. Agrarian Structure. In Social Stratification, edited by Dipankar Gupta, 261-70. New Delhi: Oxford University Press. 
Vaishnav, Milan. 2017. When Crime Pays: Money and Muscle in Indian Politics. New Haven: Yale University Press.

Wiser, William H. 1988 (1936). The Hindu Jajmani System: A Socio-Economic System Interrelating Members of a Hindu Village Community in Services. New Delhi: Munshiram Manoharlal Publishers. 